\title{
Is remote working here to stay? Lessons and ideas for a post-pandemic future
}

Armanda Cetrulo

Sant'Anna School of Advanced Studies
The article studies the impact of the Covid-19 pandemic on the labor market for what concerns the diffusion of remote working in Italy. First, it shows how working remotely represents a possibility for a minority of the workforce. Then, it discusses the presence of structural socioeconomic gaps between those who can and cannot work remotely in terms of income, unemployment, and health security at work. Finally, it addresses the issue of poor regulation on remote working by offering an overview of the national regulatory framework and describing recent trends in collective bargaining.

L'articolo studia l'impatto della pandemia Covid-19 sul mercato del lavoro dal punto di vista della diffusione del lavoro a distanza in Italia. In primo luogo, si evidenzia come lavorare a distanza sia possibile solo per una minoranza della forza lavoro. Si discute poi la presenza di divari strutturali di natura socio-economica tra coloro che possono e coloro che non possono lavorare a distanza, in termini di reddito, disoccupazione e sicurezza sanitaria sul lavoro. Infine, si affronta la questione della carenza di regolamentazione del lavoro a distanza offrendo una panoramica del quadro normativo nazionale e descrivendo le recenti tendenze nella contrattazione collettiva.

\section{Citation}

Cetrulo A. (2021), Is remote working here to stay? Lessons and ideas for a post-pandemic future, Sinappsi, XI, n.2, pp.36-49
Keywords

Remote working Inequality

Collective bargaining
Parole chiave

Lavoro a distanza

Disuguaglianza

Contrattazione collettiva

\section{Introduction}

One year after the outbreak of the global Covid-19 pandemic, the socio-economic and productive structure of entire nations is still in a state of exceptional emergency. Numerous delays in the supply of vaccines are recorded, dramatic pressures on national health systems capacities are not solved and the unequal spread of the virus worldwide is increasing the risk of uncontrolled diffusion of new variants. Despite the introduction of important novelties in terms of fiscal policies and shared funding schemes, the European Union appears still unprepared to effectively tackle the emergency.

In a context characterized by profound and

The author wishes to thank two anonymous referees for the constructive comments. This article is built upon previous works with new and updated evidence on industrial relations and collective bargaining during the pandemic. The first section is mainly based on Cetrulo et al. (2020a; 2020b) and the second section is partly based on Cetrulo (2021).

The author gratefully acknowledges the intellectual contribution of the two co-authors Maria Enrica Virgillito and Dario Guarascio and the support of the Cnel-Office IV in having provided the database on collective agreements within the COLBAR European project. The views and opinions expressed in this article are those of the author. 
collective uncertainties, however, the pandemic seems to have acted as anything but a leveller, given that its impact is asymmetrical and affects especially the most vulnerable social groups, due to profession and level of education (Montenovo et al. 2020), ethnic and geographical origin (Garcia et al. 2020), gender and family composition (European Commission 2021). In fact, the weakest strata of the population have been subject to conflating risks. First, they faced higher probabilities of contracting the virus, being mainly employed in occupations that cannot be done remotely. It is the case of 'essential' workers (not only doctors but also cleaners, supermarket cashiers, etc.) or people employed in food processing plants, logistics and manufacturing companies subject to unhealthy working conditions already before the pandemic ${ }^{1}$.

Secondly, in the absence of universal social safety nets, this part of the population had reduced access to income support measures. Women saw their socioeconomic and psychological condition dramatically worsen given their more vulnerable position in the labor market and the increased burden of care work (Cetrulo and Virgillito 2020; Arntz et al. 2020).

As far as Italy is concerned, the seriousness of the emergency, not only in terms of public health, becomes clear if we compare the economic outlook during the last quarters of 2019 and 2020 (Istat 2020a). The GDP contracted by about $6.6 \%$, while the reduction in working hours was about $7.5 \%$. Compared to 2019 , employment declined by 414,000 units $(-1.8 \%)$, a drop that is mainly concentrated among fixed-term employees $(-383,000)$ and selfemployed workers $(-129,000)$.

Certainly, both the imposed freezing of redundancies for permanent workers (in force for more than one year) and the massive public financing of furlough funds (Cassa Integrazione Ordinaria) greatly reduced the potential uneven impact of the pandemic, preserving job stability for millions of workers (Carta and De
Philippis 2021; Gallo and Raitano 2020). However, given the structural weakness of the Italian labor market and the presence of an increasing number of temporary, fictitious autonomous and informal workers, many of them had access to very limited, despite new, measures of economic support (i.e., emergency income, one-off payments for the self-employed, residual unemployment benefits for other workers) that were not designed to ensure a living income (Istat 2020a).

Moreover, from the very outbreak of the pandemic, the Italian government imposed either the closure of those activities that were not deemed essential or rather encouraged the conversion to remote work to reduce as much as possible the mobility of individuals and thus, virus circulation ${ }^{2}$.

According to Eurostat, during 2020 about $12.3 \%$ of workers in Europe were usually working from home and still nowadays a relevant part of production and service activities is performed remotely ${ }^{3}$. This change, while allowing many workers to continue their job during the pandemic, has brought to light an unprecedented distinction between workers who can and cannot perform their job from home ${ }^{4}$. Such a disruptive shift in turn encompasses two complementary issues. On the one hand, the necessity of ensuring safe working conditions, income, and employment stability for those obliged to work at their usual workplace and, on the other hand, the challenge of clearly regulating a model of work organisation that before the pandemic was concerning only a small number of workers.

This article attempts to deepen these instances. More precisely, in the first section we define the two groups of 'not working from home' and 'working from home' jobs, following the empirical methodology applied in Cetrulo et al. (2020a; 2020b). Then, we study how the two groups differentiate in terms of income level, employment security and health safety at work.

Conversely, in the second section we devote the attention to those workers that can work from home. Heterogeneity within this group is investigated with

1 See, for example, the report of EFFAT on meat-processing plants (EFFAT Report 2020).

2 There is some confusion in the debate about definitions of remote working. In this article we mainly refer to one type of remote working, namely home working/working from home, since in the context of the pandemic the only actual place of work outside the company perimeter turned out to be at workers' home. However, it is important to consider the conceptual differences between remote work, telework (i.e., remote work carried out with the help of ICT tools, as regulated in Italy by the Inter-confederal Agreement of 2004) and agile work, usually called as smart working (i.e., work carried out without precise time and space constraints, as defined by the Law n. 81/2017). For a more detailed definition, see the glossary in the Appendix.

3 https://bit.ly/3yEi72N.

4 Thereafter defined as 'working from home-WFH' and 'not working from home-NWFH'. 
respect to specific traits of the labour process, such as the degree of autonomy and the level of ICT skills. Then, given the huge diffusion of remote working practices both in private and public companies, a brief overview of the national regulatory framework is provided together with updated information on recent collective bargaining agreements at firm and sectoral level. Finally, in the Concluding remarks the main results of the analysis are presented, and considerations are made about some of the most urgent interventions needed in a post-pandemic future.

\section{Occupations' tele-workability and socio- economic disparities across workers}

During the first period of the pandemic in 2020, millions of workers have started working from home for the first time in Italy. Exact figures on the number of remote workers are not available, but estimates range from 4 million to 6.5 million workers, roughly between $18 \%$ and $35 \%$ of the entire working population, $12.2 \%$ according to Eurostat ${ }^{5}$. The change has been dramatic if we consider that between 1998 and 2018 the percentage of workers that were usually doing their work from home (predominantly in the form of telework, that is remote work carried out using ICT, see Glossary) remained stable around $3-4 \%{ }^{6}$. Before 2020 , similar numbers were recorded in most European countries, except for Northern European countries such as Finland and Denmark, which already experimented with these practices in the 1990s (Eurofound 2010).

Many policy experts and scholars have therefore hailed the so-called 'work from home experiment' as a push towards the implementation of more flexible models of work organisation as well as part of a process of technological modernisation of private companies and public administrations.

The possibility of working remotely (or more precisely of working from home, given the strict limitations to individuals' mobility) together with the massive adoption of public funded redundancy schemes, has provided many workers with a certain income stability and a lower risk of contracting the Covid-19 disease. However, as extensively documented in Cetrulo et al. (2020a; 2020b) in
Italy the percentage of workers who can perform their work remotely is limited to $30 \%$ of the entire employed workforce, corresponding to around 6.7 million of workers (calculation based on 2016 labor force survey data), whereas the huge majority of workers $(70 \%$ corresponding to around 15 million workers) cannot work from home.

How can we distinguish occupations (and workers) according to the possibility of performing job tasks remotely? What are the main differences between WFH and NWFH jobs for what concerns wage, unemployment, and health risks?

In two recent studies (Cetrulo et al. 2020a; 2020b) we propose an empirical analysis of the Italian occupation structure with the goal of answering these questions. Our analysis is based on the matching of three different databases: the Labour force survey (RFLC) conducted by the National Institute of Statistics (ISTAT) every year; the Occupations' archive of the National Institute for Occupational Accident Insurance (INAIL) and the Occupations sample survey (ICP) conducted by the National Institute for Public Policy analysis (INAPP) and Istat.

As illustrated in Cetrulo et al. (2020b), the classification of jobs according to their 'teleworkability' is built on the consideration of those predominantly physical, technical, and organisational factors that determine the way in which tasks are performed, following Dingel and Neiman (2020). It turned to be broadly consistent with available reports. As a further insight, we looked at the Italian employment structure, as defined by the ISCO classification, to understand how the 4-digit level of WFH and NWFH occupations distribute once we aggregate them into 1-digit level groups.

As Figure 1 shows, the occupational structure is highly polarised: the possibility of working remotely appears to be the prerogative of a small circle of workers belonging to the first ISCO groups, that correspond both to those managerial positions characterised by a high degree of power and autonomy and those performing administrative tasks. Furthermore, the data make it also possible to distinguish the workforce by looking at the gender dimension and account for the deep gender-segregation of the Italian occupational

5 Remote workers in Italy during Spring 2020 were more than 4 million according to Istat (2020a, Ch.2), 6.5 million according to Osservatorio Polimi and 8 million according to Fondazione di Vittorio.

6 Eurostat data 'Employed persons working from home as a percentage of the total employment, by sex, age and professional status (\%)' available at https://bit.ly/3brc6gz. 
structure. Among the WFH female workers, we see that the majority is concentrated in the Clerical and support workers (IV ISCO group), whereas they are significantly less represented in Legislators, managers, and entrepreneurs (I ISCO group); Intellectual and scientific workers (II ISCO group) with respect to their male colleagues. On the other hand, many NWFH women are employed in Service and sales workers (V ISCO group), where we find professions related to commercial activities or personal services.

Once identified occupations according to their tele-workability, we study whether these groups of workers present a different degree of vulnerability, i.e., whether they experience different risks in terms of income level, employment stability and health and safety at work. The empirical analysis is based on prepandemic data (2011-2017) because the aim is to study and identify the existence of socio-economic disparities characterising the Italian labour market in a structural way. These are likely to give rise to even greater gaps due to the continuation of the pandemic and the lack of adequate policies (Dosi et al. 2020). In fact, although it is not yet possible to have a clear picture of the impact of the pandemic on the labour market, the collapse in employment has not been recovered yet and the small rise in labour demand is mainly concentrated on precarious jobs.

Moreover, the idea of considering a multilevel risk profile looking not only at income and unemployment variables but also at health conditions at work is motivated by the awareness of the link between these factors, highlighted by the current events and summarized by the notion of 'syndemic' where different diseases interact because of socio-economic inequalities (Horton 2020). This has been confirmed by the different

Figure 1. Gender distribution at 1-digit (ISCO classification) for employees which can and cannot work from home (millions of workers)

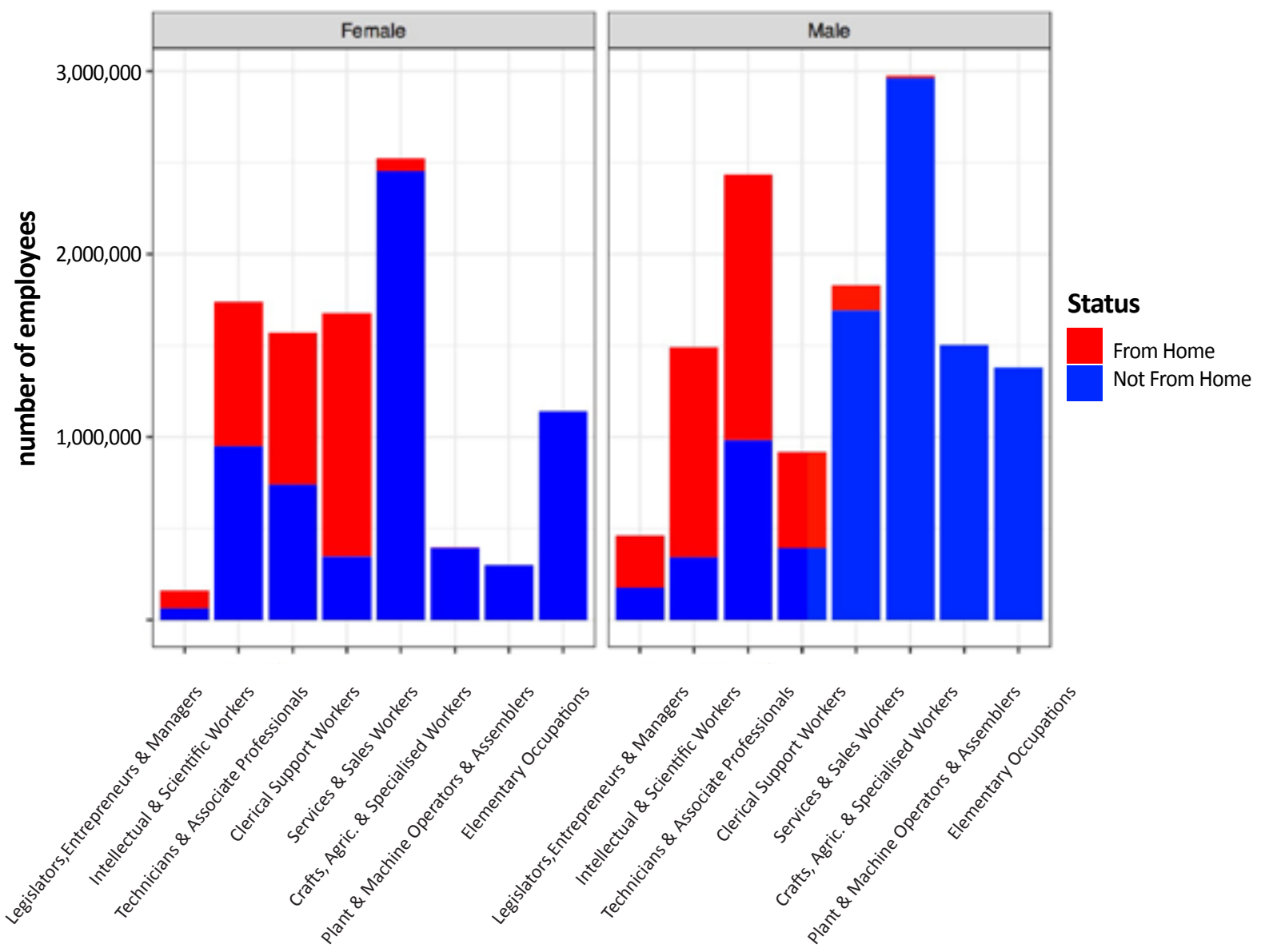


levels of mortality recorded, for example, in black communities in United States and Uk.

Our health risk variable is built on the Inail database on occupations, which collects information on job accidents at work and occupational diseases. Unlike other studies that have focused on the degree of physical proximity required to perform one's job as proxy of health risk (Barbieri et al. 2021), we believe that information as detailed as that reported by Inail on actual health and safety conditions in the workplace is a useful proxy for assessing the overall degree of protection and safety of workers (Purkayastha et al. 2021; ILO 2020).

The econometric analysis provided in Cetrulo et al. (2020b) shows that doing a job that cannot be performed from home, increases the risk of: a) earning a low wage (being in the first quantile of the population income distribution); $b$ ) losing the job (moving from an employment status to an unemployment or inactivity status); c) facing greater health risks at work.

In addition, regardless of the type of occupation, female workers are more likely to be at risk of low income than their male counterparts, while workers employed with temporary contracts face a higher risk of unemployment and low income. This is confirmed by the recent outlook of the Italian labour market, that underlines the uneven impact of the pandemic crisis on temporary workers and female workers (Istat 2020a).

\section{Remote workers: between low autonomy and unclear regulation}

The analysis described above shows that even controlling for gender, age, education level and sectors, workers that have the possibility to work from home tend to earn higher income, face lower risk of unemployment and lower risk of job accidents and occupational illness with respect to workers that cannot work from home.

However, it should not be neglected that among the $30 \%$ of potential remote workers significant disparities are at stage too. These differences do not regard only income levels, educational attainments, gender segregation and age, but also workers' degree of power and autonomy in setting goals, deadlines, the individual endowment of ICT skills and the level of cooperation with colleagues.

In a recent paper by Cetrulo et al. (2020c), we investigate the main traits of the Italian occupation structure exploiting the richness of the ICP database that contains, for each occupation, information on knowledge, social organizational structure, degree of autonomy, routinariety and technological endowment. In this study, we find out that both the attribute of autonomy, intended as the possibility of taking decision, planning deadlines, and doing the job, and power defined as the exertion of control over other people, tend to be strongly concentrated in a very limited number of occupations, all belonging to the first ISCO groups and decreasing over the ISCO classification scheme, as shown by the Figure 2.a. These findings, corroborated by recent publications of national statistics offices (Istat 2020b), gain relevance once we assume that the broad diffusion of work from home should entail giving each worker a greater degree of autonomy and flexibility in the management of his/her work. Concerning instead ICT skills defined as the degree of ICT knowledge and use of personal computer, essential for a remote worker, they are significantly under-diffused across the entire population workforce and rather confined to the II and III ISCO groups (respectively Intellectual and Scientific Workers; Specialist and Technicians Occupations) as shown by Figure 2.b.

The presence of highly hierarchical organisational and managerial models on the one hand, and the lack of specific ICT skills among the majority of workers on the other, are two fundamental aspects that make it difficult for remote working practices to be adopted smoothly and effectively. Moreover, heterogeneity in workers' socio-economic condition (gender, family composition, etc.) and location within the production process clearly turns into a completely different material experience of remote work (for a sociological fieldwork on telework in Italy see Moro 2020 and Fana et al. 2020).

Another constraint on a structural adoption of remote working certainly relates to the clarity of the current regulation, the definition of the actors involved, and the mechanisms adopted to ensure compliance with prescribed rules ${ }^{7}$. In Italy, telework has been regulated first in the public administration

7 The following paragraph on the regulation of remote working partially builds on Cetrulo (2021). 
Figure 2. The box-and-whisker plots of a) power factor score, b) ICT skills factor score

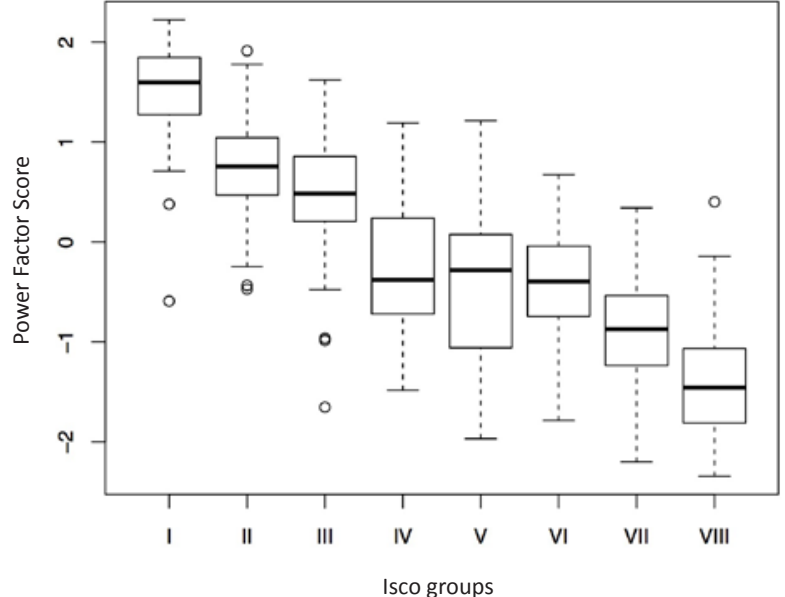

a)

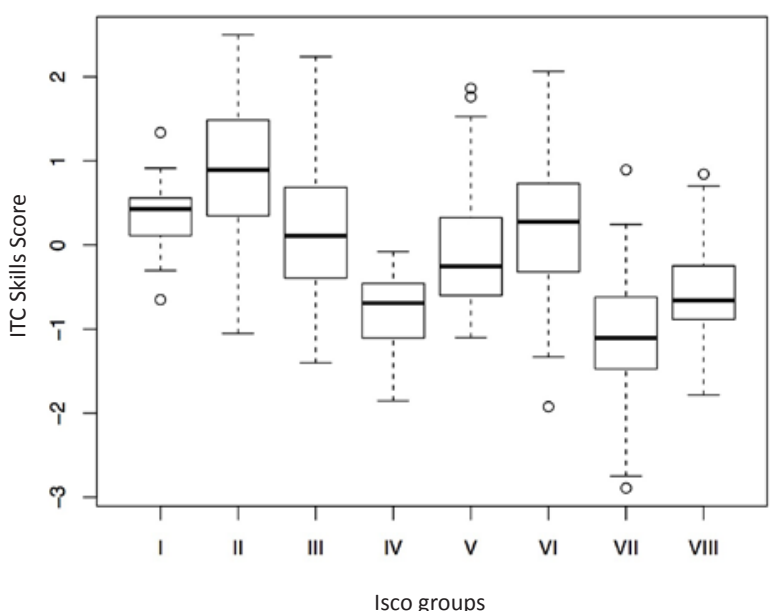

b)

Source: Cetrulo et al. 2020b, 22

sphere in 1999 (D.P.R. n. 70/1999) and afterwards, within a framework agreement for the public sector in 2000. Then, only in 2004 the private sector explicitly accounted for it with the Inter-Confederal Agreement (IA) signed by Italian employers' organisations and national trade unions. The IA was essentially transposing the European Framework Agreement (EFA) signed two years before by the European social partners. Given the detailed description of telework contained in the IA, this text represents still nowadays a fundamental source also for national collective bargaining. In fact, the agreement: i) defines telework as a subordinate type of work organisation according to which the job is performed outside the firm with the use of ICT; ii) stresses the need for voluntariness of the parties in adopting this organisational practice; iii) ensures the equality in terms of right and working conditions for teleworkers and workers in site; iv) states employers' responsibility for what concerns data security; $v$ ) imposes the respect of workers' privacy and obligation for the employer to inform workers about the adoption of monitoring technological devices; vi) assigns the employer to cover supply, installation and maintenance costs related to the equipment required (personal computer, etc.); vii) ensures workers' health and safety protection, also allowing the possibility to access the workplace with the prior worker's consent in order to verify the healthiness of the remote workplace; viii) recognises the right of the worker to manage autonomously working hours ensuring a workload comparable to those who work at the office; ix) guarantees equal rights in terms of training and career advancement to tele-workers and non-tele-workers; $x$ ) guarantees equal collective rights (participation to workers' assembly and eligibility to trade union roles).

Several other sources enrich the Italian normative framework on remote working.

First, the article 4 of the Statute of workers (L. n. 30/1970) admits the usage of technological equipment able to control workers only for organisational, production and safety reasons and with the prior consent of the trade unions (art. 4, as modified by the Jobs Act Law in 2015). The article also distinguishes between instruments of surveillance and instruments of work, where for the latter an agreement between the parties is not required. However, recent statements by the Privacy Guarantee and the National Labour Inspectorate on the use of management software and GPS technology have raised the issue of regulating the installing of 'work tools' with a high potential for surveillance and control of workers. This issue is even more urgent in the case of remote workers, since remote control becomes one of the ways through which managerial functions are exercised (Fana et al. 2021, Aloisi and De Stefano 2021). The respect of privacy and human dignity has been recently stressed also in the European Framework Agreement on Digitalisation, signed in 2020 by the European

8 Before 2015, the use of technologies able to control workers remotely was always prohibited. 
social partners and before by the European GDPR (General Data Protection Regulation) of 2016, among others. A further important reference is certainly the L. n. 66/2003 which states the impossibility of defining overtime, night work and daily rest for teleworker given the not predetermined nature of the working day . Then, the law on safety at work (L. n. 81/2008) is crucial as it recognises tele-workers as video-terminal workers and therefore entitled of several rights with respect to breaks, ergonomic workplace and medical controls on eyes and muscular disorders.

In 2017 the concept of agile work, translated in English as smart working, was introduced by the L. $\mathrm{n}$. $81 / 2017$, with the declared goal of fostering flexible modes of work organisation, improving the worklife balance, and increasing firms' competitiveness. Consistently with this formulation, priority access was granted to female workers coming back to work after maternity leaves or parents with children with disabilities and equal economic treatment is guaranteed to all workers. While telework is defined as an organisation model according to which work is performed outside the firm (presumably at home) with the use of ICT, smart working consists in a flexible work arrangement performed without precise restrictions in terms of working time and workplace (for original definitions, see the Glossary). Both the law on smart working and the IA on telework stress the necessity of an individual agreement between the employer and the employees to certify parties' voluntariness and define the modalities of these practices.

The sudden and massive adoption of remote working induced by the health emergency has certainly accelerated dramatically its diffusion, also thanks to several interventions of the national government aimed at facilitating the deployment of these practices both in the private and public sectors removing the obligation to sign agreements between the parties involved. Moreover, from the outbreak of the pandemic, trade unions have been engaging intense industrial relations at firm and sectoral level (Campolongo et al. 2021; Leonardi et al. 2021), as shown by the rising number of protocols on workplace prevention from virus infection and specific agreements on smart working ${ }^{10}$.

Just before 2020 most companies and sectors' agreements were not providing any clause on remote work. In a recent project on collective bargaining and industrial relations in Europe (Colbar), we looked at a comprehensive set of national collective agreements in Italy signed between 2010 and early 2020 and we studied the diffusion of provisions on remote work ${ }^{11}$. The sample under study is composed by 89 national collective bargaining agreements with a significant heterogeneity both in terms of sector, type of employee and date of subscription. The subset of agreements covering the private sector interests about $40 \%$ of workers (for further details on the dataset see Cetrulo 2021). Through a jointly process of texts' reading and manual annotation (Ceccon and Medas 2021), we estimated that only the $30 \%$ of the NCBAs contain specific clauses on remote work (telework and/or smart working). Among these, the majority discusses of telework, whereas rather few agreements regulate smart working, also given its more recent introduction. Moreover, while most clauses on smart working simply refer to the parties' commitment of discussing this issue, the clauses on tele-working go into detail on how this practice should be organised. Taking as reference the ten points drawn up within the IA, we assessed to which extent those provisions were integrated within national collective bargaining. Interestingly, 21 contracts out of 29 exhibiting clauses on telework, showed a medium and/or high level of detail, since they discuss at least five of the ten listed points. The outcome of the research in Cetrulo (2021) shows from one side a very scarce diffusion of provisions on remote work, but also the pivotal importance of the Inter-confederal Agreement of 2004 in setting general and easily adaptable guidelines.

If we look at most recent renewals of national collective bargaining agreements, we observe that the majority does not define precise rules on the adoption of smart working, but rather refers to the law, commits the social partners to discuss the topic in the near future, establishes bilateral commissions to monitor the outcome of undergoing experiences and keep the confrontation on most controversial issues (for details, see Table 1 in the Appendix).

Among the most discussed aspects, we can list the right of disconnection, the provision of

9 For a discussion on remote work and working time see Dagnino (2021).

10 For an updated list, consult Cnel website https://bit.ly/3h143dT.

11 Further information on the Colbar project can be found at https://bit.ly/3ncUIBS. 
Chart 1. Remote working provisions on right of disconnection, meal voucher and equipment in firm-level agreements

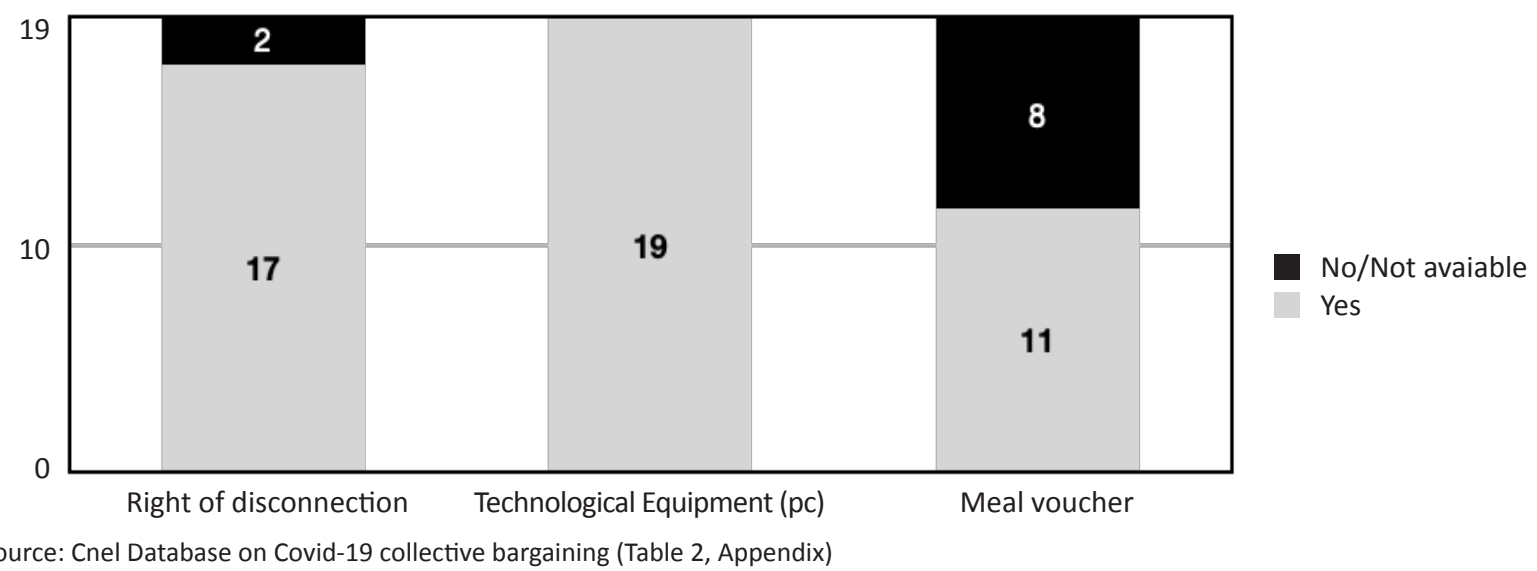

adequate equipment and safe workplace, the economic treatment, the work-life balance, the career advancement, the risk of social isolation and pervasive control. As we have seen, working time schedule for remote workers is theoretically based on workers' autonomy, within the limits of daily or weekly working hours as they are defined by industry and company collective agreements. However, several studies showed that people working remotely tend to work more than required, generally answering e-mails and phone calls in the night and find it difficult to disconnect from jobrelated issues, with a consequent risk of burnout and unpaid overtime (Eurofound and ILO 2017) ${ }^{12}$. France was the first country to introduce the right of disconnection through a law in 2016, but more recently the European Parliament approved a Resolution calling for the European right of disconnection and the Italian Parliament approved in Spring 2021 a law decree stating that the exercise of this right - necessary to protect workers' rest time and health - must be recognised without affecting the employment relationship or remuneration ${ }^{13}$.

Another issue regards the adequacy of the workplace and related technological equipment for remote workers. During the pandemic, remote workers have been obliged to work from home, often without adequate spaces and facilities, however in the future they might want to work in shared places such as co-working structures. However, this possibility conflates with the necessity of ensuring the maximum level of security of firms' data (some agreements specify that the job cannot be performed in public spaces or spaces opened to others). Moreover, concerning technological equipment, prescriptions are vague with respect to what should be provided by the company. Many agreements state the obligation for the firm to cover costs related to the personal computer, whereas only few also refers to ergonomic working tools, internet, and electricity costs.

Another set of issues relates to the induced change in the nature of the work activity, once this is performed far from the company. Especially in a context of hybrid models where a component of the workforce is working remotely and another component works from the office, problems of equal treatment arise, not only in terms of salary (as in the case of unpaid overtime or meal vouchers), but also in terms of career advancement, risk of social isolation, difficulty of coordination with colleagues who are physically gathered at the company and can communicate face to face without the use of any technology. As already anticipated, the question of limiting the adoption of control and surveillance

12 See, for instance, the results of the online survey https://bit.ly/3zH3LjB.

13 According to some law scholars, the law n. 81/2017 on the smart working also implies the right of disconnection since it states that the work must be performed within the working hours defined by collective agreements which incorporate breaks, rest time, etc. However, the law does not provide neither a specific definition of this right nor the modalities through which exercise this right (Dagnino 2021). 
tools by the employers is also crucial. The monitoring power of software, devices and new technologies can be further fostered by this massive experiment that strongly challenge traditional models of managerial control over subordinated workers.

Are these issues discussed within collective agreements? We can investigate this empirically, thanks to the availability of the Cnel updated database on industrial relations during the pandemic.

Focusing on 19 firm-level agreements, containing comprehensive guidelines on remote working, we observe that all agreements establish companies' obligation to provide workers with the required technological equipment (even if only few refers to supplementary tools like mouse, keyboard, chair, etc.). Almost all companies recognise the right of disconnection (even if its implementation remains blur in some cases) and more than $50 \%$ of the sample dispenses meal vouchers to remote workers. Clearly, these results are no representative of the entire set of undergoing agreements at firm-level, but they offer an up-to-date picture of on-going discussions.

Despite the similarity in the provisions contained in our limited sample, firms' arbitrariness can generate parallel and uneven standards of remote work depending on several factors like the model of industrial relations, the company size, the production activity, and the workforce composition.

In fact, given the presence of scarce regulation and the high degree of discretion accorded to the parties by L. n. 81/2017, different approaches emerge on how to interpret smart working. A useful example is provided by the three intersectoral protocols signed over the last year in the telecommunications sector (July 2020), chemical sector (July 2020) and insurance sector (February 2021). The three protocols cover sectors that were very much affected by the adoption of remote working during the pandemic. According to Istat survey (2020c), the rate of diffusion of remote working was $51.7 \%$ for telecommunications and $31 \%$ for the insurance sector.

Interestingly, the three protocols show different structures and contents. In the insurance sector, the agreement partly follows the model of the Interfederal Agreement. It includes important provisions as the schedule of working time within the limits defined by collective agreement, the right to disconnection, the right of training and the provision of the required equipment. The telecommunications agreement, on the other hand, advances innovative proposals that reveals the willingness to rethink more generally work organization with the goal of improving the quality of work. It discusses the possibility of reducing working hours (preserving the same salary), but also refer to the need of promoting policies against gender violence, it stresses the application of the Article 4.1 of the Workers' Statute (therefore the need of signing an agreement between parties) for what concerns the installing of working and monitoring tools. On the other hand, the protocol of the chemical sector proposes a new organisational model, based on flexibility, objectives, and results (F.O.R. Working). This model according to the parties - requires a radical cultural change. However, the modalities through which it should be implemented remain vague in the protocol and are left to firms' experiences and discretion. At the current stage, only one company has regulated the F.O.R. Working, with an agreement that stresses the role of training on hard skills (cloud computing, etc.) and soft skills (team working, remote management). Despite being at early stage, the three inter-sectoral protocols are important examples of confrontation among parties, and they confirm the necessity of defining clear rules on the way a job is performed with respect to working time, working tools and economic treatment. This need, that contradicts the rhetorical idea of a subordinated 'agile work' that can be performed without any constraint, is also confirmed by the intense activities of company level agreements recorded during the pandemic. At the same time, from a policy maker perspective, relying on second level bargaining only can generate two problems: first, not all agreements offer a broad and comprehensive regulation and can give rise to different standards; secondly it is worth to remember that while about $90 \%$ of companies are covered by national collective bargaining at sectoral level (Biagiotti et al. 2021), second level collective bargaining concerns between 20 and $30 \%$ of Italian companies.

\section{Concluding remarks}

The pandemic has uncovered the pandora's box of contradictions characterising our socio-economic structure such as the essential and invisible role of women in carrying out care activities necessary for social reproduction (ILO 2018), the weakening of the public health sector due to austerity measures (Bramucci et al. 2020; Storm 2021), the rise of precarious and poorly paid jobs and the absence of 
universal income support systems (Spasova et al. 2021). As this dramatic situation persists, the risk of a sharp increase in inequalities and a general deterioration in the living conditions of a large part of the population becomes more than concrete.

As explained in the Introduction, the world of work has been deeply shaken by the pandemic and differentiated impacts across social groups are recorded. What is more, the imposed closure of many activities and the restriction of national and international mobility has promptly induced a conversion towards models of remote working that had not been fully tested before in most countries. According to several scholars this will not result in a temporary experiment but will bring about a structural change (Barrero et al. 2020). However different issues emerge once we look at this scenario in depth.

First, the possibility of working remotely is not equally distributed among the workforce, but it rather regards a minority. Those that cannot work remotely because of technical, organisational and social features of their jobs, face higher risk of earning low income, being unemployed, having accidents at work or contracting occupational illnesses. These enduring divides, at stage well ahead of the pandemic, could significantly worsen with the continuation of the crisis.

Secondly, heterogeneity emerges also within the group of 'remote workers' when it comes to the degree of effective autonomy in performing the job and ICT skills' individual endowment. Both attributes are very scarcely diffused across the Italian occupation structure and rather concentrated in the first ISCO groups.

Thirdly, if remote working schemes are going to become a permanent feature of public and private companies, then a clear and detailed regulation is needed. As shown in Section 2, before the pandemic a limited set of national collective agreements contained clauses on remote working, largely taking over what was defined by the IA on telework signed by social partners in 2004. During the last year, however, many company level agreements have been signed but provisions are not homogenous across firms and show differences for what concerns, for instance, work organisation (i.e., implementation of the right of disconnection) and remuneration issues (i.e., meal voucher, costs covered by the company). These normative disparities can produce significant inequalities both within the firm (between remote workers and not remote workers) and across firms that belong to the same sector, despite some sectors have started an intense dialogue on the topic.

Other obstacles to a future populated by 'digital nomad workers' can be traced in the inherent nature of the labour process, for what concerns not only the persistence of hierarchical managerial models based on control and supervision, but also the very nature of collective capabilities through which firms and workers develop new ideas, learn by doing, accumulate and diffuse knowledge (Dosi et al. 2001). What is more, in the public discussion, remote working is also described as a tool able to ensure a better balance between private life and work and therefore particularly suitable for women. This prescription, however, neglects the unequal distribution of care work, that even during the pandemic has persisted and worsened (Del Boca et al. 2021).

Overall, the uncertainty and the complexity of the current situation prevent clear predictions being made, inducing a certain skepticism about positive outlooks, and rather calling for policy measures aimed at promoting equality, better working conditions and further labour regulation. 


\section{Appendix}

Table 1. Selected list of national collective bargaining agreements renewed in 2020-2021

\begin{tabular}{|c|c|c|c|c|c|}
\hline Date & Title & Sector & Employers Association & Trade unions & Main points on smart working \\
\hline 01/03/2020 & CCNL pelletteria & Textile & $\begin{array}{c}\text { ASSOPELLETTERI, } \\
\text { CONFINDUSTRIA MODA }\end{array}$ & $\begin{array}{l}\text { FILCTEM CGIL, } \\
\text { FEMCA CISL, UILTEC } \\
\text { UIL }\end{array}$ & Monitoring \\
\hline $19 / 06 / 2020$ & CCNL vetro & $\begin{array}{l}\text { Chemistry and } \\
\text { related }\end{array}$ & ASSOVETRO & $\begin{array}{l}\text { FILCTEM CGIL, } \\
\text { FEMCA CISL, UILTEC } \\
\text { UIL }\end{array}$ & Guidelines in one year \\
\hline $31 / 07 / 2020$ & $\begin{array}{l}\text { CCNL Industria } \\
\text { Alimentare }\end{array}$ & Agribusiness & $\begin{array}{l}\text { ANCIT, ANICAV, } \\
\text { ASSALZOO, ASSICA, } \\
\text { ASSITOL, ASSOBIBE, } \\
\text { Assobirra, Assocarni, } \\
\text { Assolatte, Federvini, } \\
\text { Italmopa, Mineracqua, } \\
\text { Unione Italiana Food, } \\
\text { Unionzucchero }\end{array}$ & $\begin{array}{l}\text { FLAI CGIL, FAI CISL, } \\
\text { UILA UIL }\end{array}$ & $\begin{array}{l}\text { Bilateral commission; } \\
\text { technological equipment paid by } \\
\text { the company; } \\
\text { right of disconnection }\end{array}$ \\
\hline $08 / 10 / 2020$ & CCNL Sanità Privata & $\begin{array}{l}\text { Private entities } \\
\text { and institutions }\end{array}$ & AIOP, ARIS & $\begin{array}{l}\text { FP CGIL, FP CISL, } \\
\text { FPL UIL }\end{array}$ & $\begin{array}{l}\text { Reference to the law (on } \\
\text { telework overtime work } \\
\text { allowance, economic support for } \\
\text { purchase of chair, mouse, etc.) }\end{array}$ \\
\hline $19 / 10 / 2020$ & CCNL Legno & $\begin{array}{l}\text { Construction, } \\
\text { Wood, Stone, } \\
\text { Bricks }\end{array}$ & FederlegnoArredo & $\begin{array}{l}\text { FILLEA CGIL, FILCA } \\
\text { CISL, FENEAL UIL }\end{array}$ & $\begin{array}{l}\text { Smart working: technological } \\
\text { equipment paid by the company, } \\
\text { right of disconnection (defined } \\
\text { within individual agreement) } \\
\text { welfare provisions. }\end{array}$ \\
\hline $12 / 11 / 2020$ & $\begin{array}{l}\text { CCNL imprese } \\
\text { esercenti servizi di } \\
\text { telecomunicazione }\end{array}$ & $\begin{array}{c}\text { Service } \\
\text { Companies }\end{array}$ & $\begin{array}{c}\text { Assotelecomunicazione } \\
\text { ASSTEL }\end{array}$ & $\begin{array}{l}\text { SLC CGIL, FISTEL CISL, } \\
\text { UILCOM UIL }\end{array}$ & $\begin{array}{l}\text { Reference to the Protocol } \\
\text { on smart working for the } \\
\text { Telecommunication sector } \\
\text { of } 30 / 07 / 2020 \text { (right of } \\
\text { disconnection, possible } \\
\text { reduction of working hours, } \\
\text { technological equipment given } \\
\text { by the company) }\end{array}$ \\
\hline $26 / 11 / 2020$ & CCNL Ceramica & $\begin{array}{l}\text { Chemistry and } \\
\text { related }\end{array}$ & Confindustria Ceramica & $\begin{array}{l}\text { FILCTEM CGIL, } \\
\text { FEMCA CISL, UILTEC } \\
\text { UIL }\end{array}$ & $\begin{array}{l}\text { Definition of smart working } \\
\text { and commitment to introduce } \\
\text { guidelines }\end{array}$ \\
\hline $02 / 12 / 2020$ & $\begin{array}{l}\text { CCNL cooperative } \\
\text { di trasformazione } \\
\text { di prodotti agricoli } \\
\text { e zootecnici e } \\
\text { lavorazione prodotti } \\
\text { alimentari }\end{array}$ & Agribusiness & $\begin{array}{l}\text { AGCI- AGRITAL, } \\
\text { CONFCOOPERTIVE } \\
\text { FEDAGRIPESCA, } \\
\text { LEGACOOP- } \\
\text { AGROALIMENTARE }\end{array}$ & $\begin{array}{l}\text { FLAI CGIL, FAI CISL, } \\
\text { UILA UIL }\end{array}$ & $\begin{array}{l}\text { Bilateral commission; } \\
\text { technological equipment paid by } \\
\text { the company; } \\
\text { right of disconnection }\end{array}$ \\
\hline $16 / 12 / 2020$ & $\begin{array}{l}\text { CCNL industria } \\
\text { armatoriale }\end{array}$ & Transports & $\begin{array}{c}\text { CONFITARMA, } \\
\text { Assarmatori, } \\
\text { Assarimorchiatori, } \\
\text { Federrimorchiatori }\end{array}$ & $\begin{array}{l}\text { FILT CGIL, FIT CISL, } \\
\text { UILTRASPORTI UIL }\end{array}$ & Monitoring \\
\hline 19/01/2021 & $\begin{array}{l}\text { CCNL GRAFICI E } \\
\text { EDITORI }\end{array}$ & $\begin{array}{l}\text { Polygraphs and } \\
\text { Entertainment }\end{array}$ & ASSOGRAFICI, AIE, ANES & $\begin{array}{l}\text { SLC CGIL, FISTEL CISL, } \\
\text { UILCOM UIL }\end{array}$ & $\begin{array}{l}\text { Definition of smart working, } \\
\text { reference to the law }\end{array}$ \\
\hline 05/02/2021 & $\begin{array}{l}\text { CCNL industria } \\
\text { metalmeccanica }\end{array}$ & Metalworking & $\begin{array}{l}\text { FEDERMECCANICA, } \\
\text { ASSISTAL }\end{array}$ & $\begin{array}{l}\text { FIOM CGIL, FIM CISL, } \\
\text { UILM UIL }\end{array}$ & $\begin{array}{l}\text { Bilateral commission working on } \\
\text { the regulation of smart working }\end{array}$ \\
\hline $11 / 02 / 2021$ & CCNL Tabacco & Agribusiness & A.P.T.I. & $\begin{array}{l}\text { FLAI CGIL, FAI CISL, } \\
\text { UILA UIL }\end{array}$ & $\begin{array}{l}\text { Technological equipment paid by } \\
\text { the company; } \\
\text { right of disconnection (for } \\
\text { telework meal voucher, } \\
\text { technological equipment, } \\
\text { coverage of costs related to the } \\
\text { job performance) }\end{array}$ \\
\hline
\end{tabular}

Source: Cnel, 2021 
Table 2. List of company-level collective agreements with recent provisions on remote working

\begin{tabular}{|c|c|c|c|c|c|c|}
\hline Date & Title & Firms & Trade unions & $\begin{array}{c}\text { Right of } \\
\text { disconnection }\end{array}$ & Equipment & Meal vouchers \\
\hline $03 / 02 / 2020$ & $\begin{array}{l}\text { Verbale di accordo } \\
\text { lavoro agile }\end{array}$ & $\begin{array}{l}\text { HBG Connex } \\
\text { spa; HBG } \\
\text { Entertainment } \\
\text { srl; HBG On-line } \\
\text { Gaming srl }\end{array}$ & FILCAMS CGIL; RSA & yes & $\begin{array}{l}\text { yes, but internet } \\
\text { and print costs } \\
\text { charged by the } \\
\text { worker }\end{array}$ & yes \\
\hline $24 / 02 / 2020$ & $\begin{array}{l}\text { Verbale di accordo } \\
\text { smart working }\end{array}$ & $\begin{array}{l}\text { Gruppo Crédit } \\
\text { Agricole Italia }\end{array}$ & $\begin{array}{l}\text { FABI; FIRST CISL; FISAC CGIL; } \\
\text { UILCA; UNISIN }\end{array}$ & no & yes & $\begin{array}{l}\text { no, only if } \\
\text { working at } \\
\text { the company } \\
\text { hub (previous } \\
\text { agreement) }\end{array}$ \\
\hline $11 / 05 / 2020$ & Verbale di accordo & VOIHOTELS spa & FILCAMS CGIL; FISASCAT CISL & $\begin{array}{l}\text { yes (reference } \\
\text { is made to the } \\
\text { Law 81/2008) }\end{array}$ & $\begin{array}{l}\text { yes (pc, mobile } \\
\text { phone and } \\
\text { headphones) }\end{array}$ & no \\
\hline 04/06/2020 & $\begin{array}{l}\text { Accordo sullo smart } \\
\text { working (reference to } \\
\text { previous agreements) }\end{array}$ & Gruppo HERA & $\begin{array}{l}\text { FILCTEM CGIL; FP CGIL; } \\
\text { FEMCA CISL; FIT CISL; } \\
\text { FLAEI CISL; UILTEC UIL; } \\
\text { UILTRASPORTI UIL; CISAL } \\
\text { FEDERENERGIA; FIADEL }\end{array}$ & $\begin{array}{l}\text { yes (reference } \\
\text { to previous } \\
\text { agreement) }\end{array}$ & $\begin{array}{l}\text { yes (pc and mobile } \\
\text { phone) }\end{array}$ & no \\
\hline $05 / 06 / 2020$ & $\begin{array}{c}\text { Verbale di intesa } \\
\text { lavoro agile, recupero } \\
\text { Covid-19, smaltimento } \\
\text { ferie }\end{array}$ & Intrum Italy & $\begin{array}{c}\text { FABI; FIRST CISL; FISAC CGIL; } \\
\text { UILCA; UNISIN }\end{array}$ & no & yes (pc) & no \\
\hline 09/06/2020 & $\begin{array}{l}\text { Accordo sullo } \\
\text { smart working }\end{array}$ & $\begin{array}{c}\text { ENEL ITALIA } \\
\text { (Gruppo ENEL) }\end{array}$ & $\begin{array}{l}\text { FILCTEM CGIL; FLAEI CISL; } \\
\text { UILTEC UIL }\end{array}$ & yes & $\begin{array}{l}\text { yes (mouse, } \\
\text { keyboard, monitor } \\
\text { and chair can be } \\
\text { taken from the } \\
\text { office during the } \\
\text { health emergency } \\
\text { period) }\end{array}$ & $\begin{array}{l}\text { yes (during } \\
\text { the health } \\
\text { emergency } \\
\text { period) }\end{array}$ \\
\hline 09/06/2020 & $\begin{array}{l}\text { Verbale di accordo } \\
\text { home working } \\
\text { (reference to previous } \\
\text { agreement on } \\
\text { smart working) }\end{array}$ & $\begin{array}{c}\text { Allianz Bank } \\
\text { Financial Advisors }\end{array}$ & FABI; FIRST CISL; FISAC CGIL & $\begin{array}{l}\text { yes (previous } \\
\text { agreement) }\end{array}$ & $\begin{array}{l}\text { yes (pc and data } \\
\text { connection, } \\
\text { previous } \\
\text { agreement) }\end{array}$ & $\begin{array}{l}\text { yes (previous } \\
\text { agreement) }\end{array}$ \\
\hline $15 / 07 / 2020$ & $\begin{array}{l}\text { Verbale di accordo } \\
\text { lavoro agile }\end{array}$ & Eataly srl & $\begin{array}{l}\text { FILCAMS CGIL; FISASCAT } \\
\text { CISL; UILTUCS UIL }\end{array}$ & yes & yes & no \\
\hline $17 / 07 / 2020$ & $\begin{array}{l}\text { Accordo smart } \\
\text { working }\end{array}$ & Fincantieri spa & $\begin{array}{l}\text { FIM CISL; FIOM CGIL; UILM } \\
\text { UIL }\end{array}$ & yes & yes & no \\
\hline 04/08/2020 & $\begin{array}{l}\text { Verbale di accordo in } \\
\text { tema di lavoro agile } \\
\text { c.d. smart working }\end{array}$ & $\begin{array}{l}\text { ING Bank N.V. } \\
\text { Succursale di } \\
\text { Milano }\end{array}$ & $\begin{array}{l}\text { RSA FABI; RSA FIRST CISL; } \\
\text { RSA FISAC CGIL; RSA UILCA; } \\
\text { RSA UNISIN }\end{array}$ & yes & $\begin{array}{l}\text { yes (pc provided } \\
\text { by the company); } \\
\text { workers are } \\
\text { supposed to } \\
\text { have good wi-fi } \\
\text { connection; bonus } \\
\text { for chairs, etc } \\
\text { (max } 90 \text { euro) }\end{array}$ & no \\
\hline 04/08/2020 & $\begin{array}{l}\text { Verbale di accordo } \\
\text { lavoro agile }\end{array}$ & TIM spa & $\begin{array}{c}\text { SLC CGIL; FISTEL CISL; } \\
\text { UILCOM UIL; UGL } \\
\text { Telecomunicazioni; RSU }\end{array}$ & yes & $\begin{array}{l}\text { yes (wi-fi for those } \\
\text { working with } \\
\text { clients) }\end{array}$ & yes \\
\hline $21 / 09 / 2020$ & $\begin{array}{l}\text { Verbale di accordo in } \\
\text { materia di lavoro agile }\end{array}$ & $\begin{array}{c}\text { Cassa Centrale } \\
\text { Banca - Credito } \\
\text { Cooperativo } \\
\text { Italiano spa }\end{array}$ & $\begin{array}{l}\text { FABI; FIRST CISL; FISAC CGIL; } \\
\text { UILCA UIL; FILCRA UGL }\end{array}$ & yes & yes & yes \\
\hline $29 / 09 / 2020$ & $\begin{array}{l}\text { Verbale di accordo } \\
\text { smart working }\end{array}$ & $\begin{array}{l}\text { Fastweb spa - } \\
\text { Fastweb Air srl }\end{array}$ & $\begin{array}{c}\text { SLC CGIL; FISTEL CISL; } \\
\text { UILCOM UIL; UGL } \\
\text { Telecomunicazioni; RSU }\end{array}$ & yes & yes & yes \\
\hline $18 / 12 / 2020$ & $\begin{array}{l}\text { Verbale di accordo sul } \\
\text { lavoro agile }\end{array}$ & $\begin{array}{l}\text { POSTE ITALIANE } \\
\text { SpA }\end{array}$ & $\begin{array}{l}\text { SLC CGIL; SLP CISL; UIL } \\
\text { POSTE; FAILP CISAL; } \\
\text { CONFSAL Comunicazioni; } \\
\text { FNC UGL Comunicazioni }\end{array}$ & yes & $\begin{array}{l}\text { yes (pc, tablet, } \\
\text { and company } \\
\text { smartphone); } \\
\text { discussion on } \\
\text { affordable wi-fi } \\
\text { connections }\end{array}$ & yes \\
\hline
\end{tabular}

Source: Cnel database (https://bit.ly/3DMIdEs) 


\section{Glossary \\ Tekework}

Telework is a form of organising and/or performing work, using information technology, in the context of an employment contract/relationship, where work, which could also be performed at the employer's premises, is carried out away from those premises on a regular basis.

Source: European Framework Agreement 2002 (https://bit.ly/38AGaVZ); original text

\section{Home Work}

According to ILO Home Work Convention (1996, art.1):

(a) the term home work means work carried out by a person, to be referred to as a homeworker, i) in his or her home or in other premises of his or her choice, other than the workplace of the employer;

i. for remuneration;

ii. which results in a product or service as specified by the employer, irrespective of who provides the equipment, materials or other inputs used,

iii. unless this person has the degree of autonomy and of economic independence necessary to be considered an independent worker under national laws, regulations or court decisions;

(b) persons with employee status do not become homeworkers within the meaning of this Convention simply by occasionally performing their work as employees at home, rather than at their usual workplaces;

(c) the term employer means a person, natural or legal, who, either directly or through an intermediary, whether or not intermediaries are provided for in national legislation, gives out home work in pursuance of his or her business activity.

Source: ILO Home Work Convention 1996 (No.177) - Available at https://bit.ly/2YpkASr; original text

\section{Smart-work/ Agile working}

Agile working is a mode of execution of the employment relationship established by agreement between the parties, including forms of organisation by stages, cycles, and objectives and without precise constraints on working hours or place of work, with the possible use of technological instruments required for the work activity. The work is carried out partly at the company and partly outside without a fixed workstation, within the limits of the maximum duration of daily and weekly working time defined by the law and by collective bargaining.

Source: Italian Law n. 81/2017, art.18 (https://bit.ly/3gYe0ZE); author's translation

\section{References}

Aloisi A., De Stefano V. (2021), Essential jobs, remote work and digital surveillance: addressing the COVID-19 pandemic panopticon, International Labour Review, forthcoming

Arntz M., Berlingieri F., Yahmed S. B. (2020), Working from Home and COVID-19. The Chances and Risks for Gender Gaps, Intereconomics, 55, n.6, pp.381-386

Barbieri T., Basso G., Scicchitano S. (2021), Italian workers at risk during the Covid-19 epidemic, Italian Economic Journal, pp.1-21

Barrero J.M., Bloom N., Davis S.J. (2020), Why Working from Home Will Stick, Working Paper n.174, Chicago, Becker Friedman Institute for Economics

Biagiotti M., Tomaro S., Venturi L. (2021), Un progetto per il nuovo archivio della contrattazione collettiva, in Cnel, XXII Rapporto. Mercato del lavoro e contrattazione collettiva 2020, Roma, Cnel, pp.227-242

Bramucci A., Prante F.J., Truger A. (2020), Decades of tight fiscal policy have left the health care system in Italy ill-prepared to fight the COVID-19 outbreak, Intereconomics, 55, n.3, pp.147-152

Campolongo F., lannuzzi F.E., Piro V., Romens A.I (2021), Negoziare la remotizzazione: strategie sindacali sul lavoro agile. Una ricerca nel contesto veneto, Prepared for the AISRI Online Conference II lavoro e le relazioni industriali dopo la pandemia: nuovi sguardi, 8-9 April 2021

Carta F., De Philippis M. (2021), The impact of the COVID-19 shock on labour income inequality: Evidence from Italy, Occasional papers n.606, Rome, Bank of Italy

Ceccon D., Medas G. (2021), Codebook Wage Indicator Collective Agreements Database, Amsterdam, Wage Indicator Foundation

Cetrulo A. (2021), National collective bargaining agreements in Italy: an investigation on wages and remote working. COLBAREUROPE, s.l., University of Amsterdam, Celsi, Cnel <https://bit.ly/3yOml7Z>

Cetrulo A., Guarascio D., Virgillito M. E. (2020a), The privilege of working from home at the time of social distancing, Intereconomics, 55, n.3, pp.142-147

Cetrulo A., Guarascio D., Virgillito M. E. (2020b), Working from home and the explosion of enduring divides: income, employment and safety risks, LEM Working Papers Series n.38), Pisa, Sant'Anna School of Advanced Studies <https://bit.ly/3DJCKyd>

Cetrulo A., Guarascio D.Virgillito M.E. (2020c), Anatomy of the Italian occupational structure: concentrated power and distributed knowledge, Industrial and Corporate Change, 29, n.6, pp.1345-1379 
Cetrulo A., Virgillito M.E. (2020), Dicotomie di genere: tra lavoro da casa e lavoro di cura, in Cigna, L. (a cura di) Forza Lavoro! Ripensare il lavoro al tempo della pandemia, Quaderni n.37 Milano, Fondazione Giangiacomo Feltrinelli

Dagnino E. (2021), La regolazione dell'orario di lavoro nell'era del working anytime, anywhere. Spunti dalla disciplina italiana del lavoro agile e del diritto alla disconnessione, Working paper n.5, Salus-Adapt <https://bit.ly/3DOjArf >

Del Boca D., Oggero N., Profeta P., Rossi M.C, Villosio C. (2021), Women's Working Behavior and Household Division of Labor During the two Waves of COVID-19 in Italy, Torino, Fondazione Compagnia di San Paolo- Collegio Carlo Alberto

Dingel J.I., Neiman B. (2020), How many jobs can be done at home?, Journal of Public Economics, 189, n.2, p.104235

Dosi G., Fanti L., Virgillito M.E. (2020), Unequal societies in usual times, unjust societies in pandemic ones, Journal of Industrial and Business Economics, 47, n.3, pp.371-389

Dosi G., Nelson R.R., Winter S.G. (eds) (2001), The nature and dynamics of organizational capabilities, Oxford, Oxford University Press

EFFAT (2020), Report Covid-19 outbreaks in slaughterhouses and meat processing plants. State of affairs and proposals for policy action at EU level, Brussels, EFFAT

Eurofound (2010), Telework in the European Union, Technical Report, Retrieved, September 17, 2021, <https://bit.ly/2VfbTZG>

Eurofound, ILO (2017), Working anytime, anywhere: The effects on the world of work, Luxembourg, Publications Office of the European Union- Geneva, International Labour Office <https://bit.ly/3jRkGKK>

European Commission (2021), 2021 report on gender equality in the EU, Brussels, European Union

Fana M., Massimo F.S., Moro A. (2021), Autonomy and control in mass remote working during the Covid-19 pandemic. Evidences from a cross-professional and cross-national analysis, forthcoming

Fana M., Milasi S., Napierala J., Fernandez-Macias E., Vazquez I.G. (2020), Telework, work organisation and job quality during the COVID-19 crisis: a qualitative study, JRC Working Papers Series on Labour, Education and Technology n.11, Seville, European Commission

Gallo G., Raitano M. (2020), SOS incomes: Simulated effects of COVID-19 and emergency benefits on individual and household income distribution in Italy, Working paper series n.566, ECINEQ

Garcia M., Homan P., García C., Brown T. (2020), The Color of COVID-19: Structural Racism and the Pandemic's Disproportionate Impact on Older Black and Latinx Adults, The Journals of Gerontology, Psychological Sciences and Social Sciences, XX, n.20, pp.1-6

Horton R. (2020), Offline: COVID-19 is not a pandemic, The Lancet, 396, n.9

ILO (2021), Working from home: From invisibility to decent work, Geneva, International Labour Office

ILO (2020), COVID-19: Protecting workers. Keys for effective teleworking during the COVID-19 pandemic, Geneva, International Labour Office

ILO (2018), Care work and care jobs for the future of decent work, Geneva, International Labour Office

Istat (2020a), II mercato del lavoro 2020. Una lettura integrata, Roma, Istat

Istat (2020b), L'organizzazione del lavoro in Italia: orari, luoghi, grado di autonomia. Anno 2019, Roma, Istat

Istat (2020c), Rilevazioni sull'impatto dell'emergenza Covid-19 sulle imprese italiane, Roma, Istat

Leonardi S., Munno A.R., Spiller S., Pata I., Morleo G., Passarello G., Baldazzi P., Massimiano E., De Carli M., Gatto B., Cianchi V., Falcioni F. (2021), Contrattazione decentrata in tempo di COVID-19, in Cnel, XXII Rapporto. Mercato del lavoro e contrattazione collettiva 2020, Roma, Cnel, pp.87-114

Montenovo L., Jiang X., Rojas F. L., Schmutte I. M., Simon K. I., Weinberg B. A., Wing C. (2020), Determinants of disparities in COVID-19 job losses, NBER Working Paper Series n.27132, Cambridge, National Bureau of Economic Research

Moro A. (2020), Impact of the Covid-19 confinement measures on telework in Italy.A qualitative survey, JRC Working Paper Series on Labour, Education and Technology n.10, Seville, European Commission

Purkayastha D., Vanroelen C., Bircan T., Vantyghem M.A., Gantelet Adsera C. (2021), Work, health and Covid-19, Brussels, ETUI European Trade Union Institute <https://bit.ly/3DLq3TC>

Spasova S., Ghailani D., Sabato S., Coster S., Fronteddu B., Vanhercke B. (2021), Non-standard workers and the self-employed in the EU, Brussels, ETUI European Trade Union Institute <https://bit.ly/3kPFHoo>

Storm S. (2021), Lessons for the Age of Consequences: COVID-19 and the macroeconomy, Woking paper n.152, New York, Institute for New Economic Thinking

\section{Amanda Cetrulo}

armanda.cetrulo@santannapisa.it

Armanda Cetrulo is a PhD student candidate in Economics at Sant'Anna School of Advanced Studies, Pisa. Her research interests focus on technology, work organisation and industrial relations. She has extensively worked on Italian labor market data, looking at the characteristics of the occupational structure and at the relation between occupations' degree of tele-workability and heterogeneity of risks. She has published her research on Applied Economics, Journal of Industrial and Business Economics, Intereconomics and Industrial and Corporate Change. 